\title{
The Water Quality Detection in Fuyang River (Hengshui Section)
}

\author{
Zhongqiang Zhang ${ }^{1, a *}$, Yan Wang ${ }^{1, b}$, Yan Zhang ${ }^{1, c}$, Quying Lin $^{1, d}$ and \\ Wenwen Wang ${ }^{1, e}$
}

\author{
${ }^{1}$ Department of Applied Chemistry, Hengshui University,Hengshui City, Hebei Province, 053000, \\ P.R. China \\ azhangzhongqiang@126.com, ${ }^{\text {b } 1774539895 @ q q . c o m, ~}{ }^{\mathrm{c}}$ 67129206@qq.com, ${ }^{\mathrm{d}} 1014144909 @ q q . c o m$, \\ 3290661148@qq.com
}

*The corresponding author

Keywords: Fuyang river; Water quality; Detection; Heavy metal ions; Concentration

\begin{abstract}
The water quality in Fuyang River (hengshui section) had been detected by atomic absorption spectroscopy analysis and titration analysis and other analysis methods, such as, the hardness, turbidity, coloration, $\mathrm{pH}$, conductivity and the content of four kinds of heavy metal ions. The test results showed that Fuyang River water was light yellow, Turbidity is $5.38 \mathrm{NTU}, \mathrm{pH}$ is 6.36 and weakly acidic, the electrical conductivity of water is $376 \mu \mathrm{s} / \mathrm{cm}$ at $23.2{ }^{\circ} \mathrm{C}$, Hardness (in terms of calcium oxide) was $10.92 \mathrm{mg} / \mathrm{L}$; The four kinds of heavy metal ions of mercury, lead, chromium, and cadmium had been determined by atomic absorption spectrophotometer. The results showed that the concentration of lead ion was $86.636 \mu \mathrm{g} / \mathrm{L}$, and the other three kinds of heavy metal ions of mercury, chromium, cadmium were not detected.
\end{abstract}

\section{Introduction}

Fuyang River originates in Handan Fengfeng Mining area, the south of Taihang Mountains ${ }^{[1]}$. It flows Handan City, Xingtai City, Hengshui City, and converges with Hutuo River to designate the name that is Ziya River at Xixian County in Cangzhou City. The total length of Fuyang River is 413 $\mathrm{km}$. It is the backbone river for the comprehensive utilization, includes flood control, irrigation, drainage, and shipping, etc. It is a perennial water natural river. In recent years, it suffered serious pollution due to the development of industry and agriculture ${ }^{[2-6]}$. The Hengshui City comprehensive management program for urban rivers was a few suitable aquatic plants had been grow at the water area to make full use of the favorable conditions of biological water purification by adjusting measures to local conditions. The Fuyang river (Hengshui section) water quality had a qualitative change with the help of the function of decomposition, absorption and transformation of pollutants in water by the plant propagation and consumption of nutrients and biological reactions in recent years $^{[7-9]}$. So the Fuyang River (Hengshui section) of water environmental conditions will be grasped in time by the water quality monitoring accurately, and to provide technical support for the decision of relevant administration departments ${ }^{[10,11]}$.

\section{Experiment}

Reagent and Instrument. The reagents used in the experiment were all analytically

pure and without further purification, such as chrome black T, EDTA, sodium chloride, sulfuric acid, nitric acid, hydrochloric acid, ammonium chloride, sodium hydroxide, mercury nitrate, lead nitrate, potassium dichromate, etc. but metal cadmium was pure spectrum.

Instruments. $50 \mathrm{~mL}$ colorimetric tube with a plug, electronic balance (FA2004N, Shanghai precision scientific instrument co., LTD.), $\mathrm{pH}$ meter (pHS-3C precision $\mathrm{pH}$ meter, Shanghai precision scientific instrument co., LTD.), turbidity meter (SYL-1, Shanghai Xinrui co., LTD.), conductivity meter (DOS - 307 conductivity meter, Shanghai Shengci instrument co., LTD), atomic absorption spectrometer (AFG atomic absorption spectrophotometer, Beijing Haiguang Instrument Co., Ltd.). 
The Experimental Process. Determination Coloration of Sample Water. Determination coloration of sample water by cobalt chromium colorimetric method: first of all, The sample water was centrifuged and the supernatant liquor was determined. The $50 \mathrm{~mL}$ sample water from Fuyang River disposed compared to the cobalt chromium standard solution, The coloration of Fuyang River water was 35.

Determination the Turbidity of Sample Water. The turbidity of sample water was determined by a turbidity meter. The average value of three turbidity determined was 5.38NTU.

Determination the Hardness of Sample Water. $50.0 \mathrm{~mL}$ sample water had been moved accurately to $250 \mathrm{~mL}$ conical flask, and acidified by adding 1 to 2 drops of $0.1 \mathrm{~mol} / \mathrm{L} \mathrm{HCl}$ solutions. $\mathrm{CO}_{2}$ had been removed from sample water by boiling for a few minutes. After cooling, $3 \mathrm{~mL}$ triethanolamine solution ( $200 \mathrm{~g} / \mathrm{L})$ was added. $\mathrm{NH}_{3}-\mathrm{NH}_{4} \mathrm{Cl}$ buffer solution had been used to adjust the $\mathrm{pH}$ of solution at $\mathrm{pH}=10.1 \mathrm{~mL} 20 \mathrm{~g} / \mathrm{L} \mathrm{Na} 2 \mathrm{~S}$ solution had been added to conical flask, then added 3 drops of chrome black $\mathrm{T}$ indicator in it, and determined immediately by titration with EDTA standard solution. It was the end point when the solution changed from red to pure blue. In 3 parallel determination and calculation of total hardness of sample water (in terms of calcium oxide) is $10.92 \mathrm{mg} / \mathrm{L}$.

Determination the pH of Sample Water. The sample water $\mathrm{pH}$ value had been determined coarse by using the $\mathrm{pH}$ test paper, and precise $\mathrm{pH}$ value had been determined by precise $\mathrm{pH}$ meter. The sample water $\mathrm{pH}$ value was 6.36, and it showed weak acid.

Determination of Electrical Conductivity of Sample Water. the electrical conductivity of sample water had been measured by conductivity meter. the electrical conductivity of sample water was $376 \mu \mathrm{s} / \mathrm{cm}$ at $23.2{ }^{\circ} \mathrm{C}$.

Determination the Content of Heavy Metal Ions in Sample Water. Counteracting of sample water. $50 \mathrm{~mL}$ concentrated nitric acid had been added in $100 \mathrm{~mL}$ sample water, then heated to $85 \mathrm{~mL}$ by boiling for a few minutes. $2 \mathrm{~mL} 30 \%$ hydrogen peroxide and $5 \mathrm{~mL}$ concentrated nitric acid had been added in above liquid, and heated to $70 \mathrm{~mL}$. Then $2 \mathrm{~mL} \mathrm{NH}_{4} \mathrm{Cl}$ solution $(1 \mathrm{~mol} / \mathrm{L})$ and $10 \mathrm{~mL}$ $\mathrm{HCl}$ solution $(3 \mathrm{~mol} / \mathrm{L})$ had been added in above liquid, cooled to room temperature, and then prepared the constant volume to $100 \mathrm{~mL}$ volumetric flask.

Preparation for standard solution of four kinds of heavy metal ions. Preparation for standard solution of mercury ions: $0.1620 \mathrm{~g}$ mercury nitrate was weighted accurately, $10 \mathrm{~mL} 0.1 \mathrm{~mol} / \mathrm{L}$ nitric acid was added in it to dissolve, and prepared the constant volume to $100 \mathrm{~mL}$ volumetric flask. The concentration of solution was $1 \mathrm{mg}$ mercury ions per milliliter. The standard solution of mercury ions had been diluted into different concentration gradient of solution in a series of volumetric flasks.

Preparation for standard solution of lead ions. $0.1598 \mathrm{~g}$ lead nitrate was weighted accurately, 10 $\mathrm{mL} 1 \mathrm{~mol} / \mathrm{L}$ nitric acid was added in it to dissolve, and prepared the constant volume to $100 \mathrm{~mL}$ volumetric flask. The concentration of solution was $1 \mathrm{mg}$ lead ions per milliliter. The standard solution of lead ions had been diluted into different concentration gradient of solution in a series of volumetric flasks.

Preparation for standard solution of chromium ions: $2.8289 \mathrm{~g}$ drying potassium dichromate that had been at $120{ }^{\circ} \mathrm{C}$ for four hours was weighted accurately, and prepared the constant volume to $1000 \mathrm{~mL}$ volumetric flask. The concentration of solution was $1 \mathrm{mg}$ chromium ions per milliliter. The standard solution of chromium ions had been diluted into different concentration gradient of solution in a series of volumetric flasks.

Preparation for standard solution of cadmium ions: $1.0000 \mathrm{~g}$ spectral purity metal cadmium was weighted accurately, $10 \mathrm{~mL} 1+1$ nitric acid was added in it to dissolve, and prepared the constant volume to $1000 \mathrm{~mL}$ volumetric flask. The concentration of solution was $1 \mathrm{mg}$ cadmium ions per milliliter. The standard solution of cadmium ions had been diluted into different concentration gradient of solution in a series of volumetric flasks. 


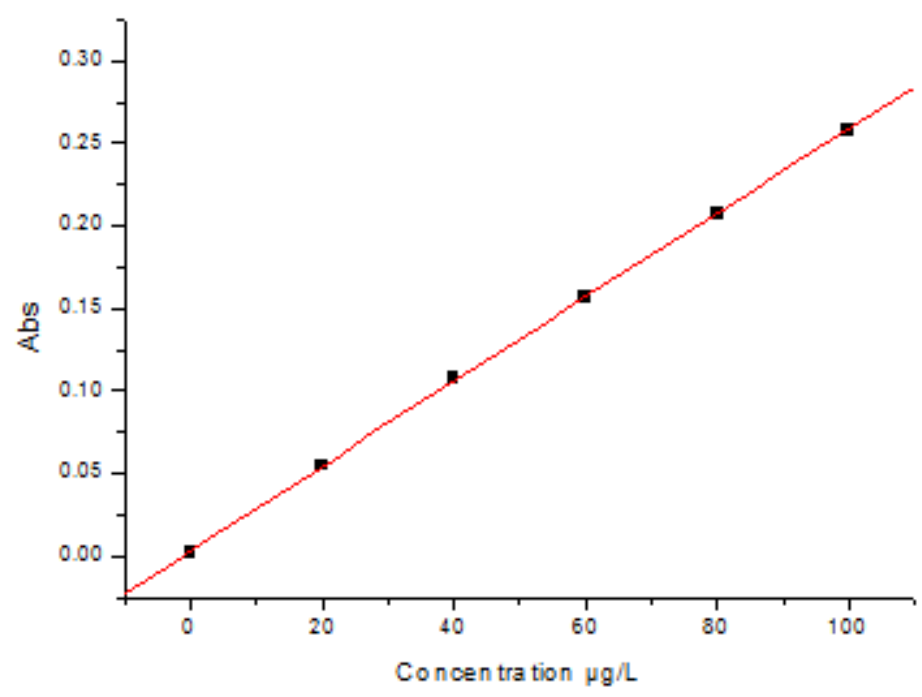

Figure 1. Standard curve of lead ions linear equation: $\mathrm{y}=0.0025647 \mathrm{x}+0.0153$. $\mathrm{R}^{2}=0.9999$

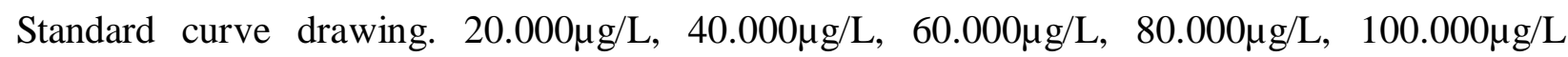
mercury ions standard solution and blank samples were taken to determine the absorbance value on the atomic absorption spectrometer, and the standard curve had been drawn. The standard curves of other three metal ions had been drawn by a similar method (Fig .1). The linear correlation coefficient $\left(\mathrm{R}^{2}\right)$ of standard curve for mercury ions, lead ions, chromium ions, and cadmium ions were 0.9978. 0.9999, 0.9985, and 0.9986, respectively.

Detection result. The results of determination the content of heavy metal ions in sample water were that the sample water only contained lead ions, the lead ions content was $86.636 \mu \mathrm{g} / \mathrm{L}$, and other three kinds of heavy metal ions were not detected. A health based guideline value of $10 \mu \mathrm{g} / \mathrm{L}$ lead in drinking water was developed by WHO in 1993. So the concentration of lead ions in water of Fuyang River (hengshui section) was much higher than the WHO drinking water standard. But it was met the national V categories of Environmental Quality Standards for Surface Water $(\mathrm{GB} 3838-2002)^{[13]}$.

\section{Conclusions}

The water quality in Fuyang River (hengshui section) had been detected by atomic absorption spectroscopy analysis and titration analysis and other analysis methods, such as, the hardness, turbidity, coloration, $\mathrm{pH}$, and conductivity, etc. The results of determination as follows: The water color of FuYang River was light yellow, and the coloration of Fuyang River water was 35; Turbidity parallel determination for three times average $5.38 \mathrm{NTU}$; $\mathrm{pH}$ was 6.36 and weakly acidic; The electrical conductivity of water was $376 \mu \mathrm{s} / \mathrm{cm}$ at $23.2{ }^{\circ} \mathrm{C}$; Hardness (in terms of calcium oxide) was $10.92 \mathrm{mg} / \mathrm{L}$; The four kinds of heavy metal ions of mercury, lead, chromium, and cadmium had been determined by atomic absorption spectrophotometer. The results showed that the concentration of lead ion was $86.636 \mu \mathrm{g} / \mathrm{L}$, and the other three kinds of heavy metal ions of mercury, chromium, cadmium were not detected. The detection results showed that the concentration of lead ions in water of Fuyang River (hengshui section) was much higher than the WHO drinking water standard. But it was met the national V categories of Environmental Quality Standards for Surface Water (GB3838 -2002).

\section{Acknowledgements}

This work was supported by Colleges and universities in Hebei Province science and technology research projects (No. Z2015142). 


\section{References}

[1] Ping Li, Journal of Green Science and Technology, (2013) No.6,p.191(In Chinese)

[2] Y.H.Wei, Journal of Hengshui normal college, Vol.5 (2003)No.1, p.47(In Chinese)

[3] X.C. Li, C. Li, Journal of Hengshui normal college, (2010)No.11, p.3(In Chinese)

[4] H.X. Wang, W.Y. Qiu, Journal of Hengshui normal college,Vol.4(2002) No.3, p.1(In Chinese)

[5] Y.W. Li, Y. Zhang and H. Zhang, Journal of Henan science and technology,(2014)No.7, p.1 178(In Chinese)

[6] S. Feng, S.R. Wang, X.X. Li, Water Conservancy Development Research, (2015)No.5, p.66(In Chinese)

[7] L.H. Yang, S.P. Zong and J.S. Jia, Journal of Haihe River water conservancy, (2014)No.1,p.12(In Chinese)

[8] H.X. Zhao, Industry and Technology Forum, Vol. 12(2012)No.2, p.131(In Chinese)

[9] R.B Jia, S.H. Sun, Water quality detection technology of urban water supply(Chemical Industry Press, China 2014)(In Chinese)

[10]F.F. Shi, G.Y. Ren, Journal of Yunnan Minzu University(Social Sciences), Vol. 32(2015)No.5,p.38(In Chinese)

[11]Z.J. Yan, M.Y. Zhang, J.S. Zhang, S.L. Zhang, H.R. Wang, W.H. Chen, and C. Chen, Water Conservancy,(2014)No.7, p.3(In Chinese)

[12] A.J. Gong, J.M. Liu, and H.O. Wang, Environmental Chemistry (Undergraduate program for general higher education in bilingual education in 12th Five-Year)(Chemical Industry Press, China 2016)(In Chinese)

[13] GB3838-2002.Environmental Quality Standards for Surface Water(State Standard of the People's Republic of China)[S], Beijing: China Standard Press 